\title{
Fostering Muslim Civic Engagement THROUGH FAITH-BASED COMMUNITY ORGANIZING
}

\author{
Brad R. Fulton \\ Indiana University Bloomington
}

\begin{abstract}
Muslims often encounter discriminatory practices similar to those experienced by other minority groups living in the United States. Such practices range from mass incarceration and anti-immigration efforts to racial and religious profiling. In response, a growing number of U.S. Muslim leaders are organizing their communities and collaborating with non-Muslims to address these issues through civic participation and political action. At the same time, several foundations throughout the country have begun asking how to promote civic engagement among U.S. Muslims. Although little is known about U.S. Muslim civic engagement and its outcomes, data from a national study indicate that faithbased community organizing is becoming a viable pathway for Muslim communities to (1) strengthen themselves internally by developing civic leaders and mobilizing everyday Muslims to address issues affecting their community and (2) strengthen their external ties by bridging religious and social differences and by promoting policies that also benefit non-Muslims.
\end{abstract}

Keywords: Muslim, civic engagement, faith-based, community organizing, philanthropy

Muslims often encounter discriminatory practices similar to those experienced by other minority groups living in the United States. Such practices range from mass incarceration and antiimmigration efforts to racial and religious profiling. In response, a growing number of U.S. Muslim leaders are organizing their communities and collaborating with non-Muslims to address these issues through civic engagement and political participation.

This article begins by highlighting several forms of Muslim civic engagement and collaboration in the post-9/11 era. Then it describes one specific form-faith-based community organizing - and explores recent trends with respect to U.S. Muslims' civic engagement via this form of organizing. Particular attention is given to the degree to which U.S. Muslims, as a minority community, have discovered both the necessity and the benefits of organizing with people from other faith traditions as a type of intersectional activism for social change.

Copyright $\odot 2017$ Brad R. Fulton

http://scholarworks.iu.edu/iupjournals/index.php/jmp

DOI: https://doi.org/10.18060/21406 


\section{Muslim Civic Engagement and Collaboration in the Post-9/11 Era}

In the immediate aftermath of the September 11 attacks in 2001 and the attendant threats to the civil rights of Muslims, Muslim communities across the United States realized the urgent need to develop new modes of organized and strategic engagement with the broader civil society. By the latter half of the 2000s, the interfaith organizing efforts of U.S. Muslims began to cross the threshold of public visibility. In May of 2007, for example, members of Chicago's Inner-City Muslim Action Network (IMAN), a social justice-oriented nonprofit, joined thousands of nonMuslim community members for a May Day immigration rally (Lyden, 2013). IMAN's participation in this march was part of its ongoing effort to partner with other local organizations to advocate for the rights of immigrant families and communities. This collaborative spirit is reflected in most of IMAN's activities, which include tackling inner-city food deserts, advocating for juvenile offenders, and promoting small businesses in low-income communities (Parsons, 2013). In addition, IMAN's annual Takin' It to the Streets festival, which seeks to promote cooperation among Chicago's residents, draws several thousand participants each year (Freedman, 2014). As IMAN bridges racial, ethnic, and religious divides, it is also successfully organizing and mobilizing thousands of Muslims in Chicago to become civically engaged and address the challenges facing their communities (Lyden, 2013).

In January 2013, a group of 125 Muslim, Christian, and Jewish activists gathered in an Upper West Side church to mobilize against Islamophobia and "stop and frisk" practices in New York City (Kane, 2013). This event, which highlighted commonalities among these forms of discrimination, bolstered a growing coalition between Muslim organizations addressing antiMuslim hate crimes, Black and Latino organizations opposing racial profiling, and Jewish organizations supporting their work. Linda Sarsour, a Palestinian-American Muslim, explained, "Whether you're spying on the Muslim community or stopping and frisking Blacks and Latinos, it's the same thing. Let's stop separating the issues" (Kane, 2013:1). With a shared opposition to criminalizing communities of color, these organizations have joined together to advocate for bills to reform NYPD practices and increase police accountability. Spearheading this collaborative effort is the Communities United for Police Reform, which is a racially and religiously diverse coalition that is supported in large part by $\$ 2.2$ million in grants from the Open Society Foundations (Goodman, 2013).

In March 2014, nearly 100 Muslims in the San Francisco Bay Area, along with 100 other concerned citizens, attended an Oakland City Council meeting to oppose the creation of a $\$ 11$ million Department of Homeland Security funded surveillance center (Winston, 2014). The proposed Domain Awareness Center would have aggregated information from nearly 1,000 video cameras, sensors, social media feeds, and real-time data to track the activities of people throughout the Oakland city limits. As the Muslim community members provided public testimony to the city council, they shifted the discussion to highlight concerns about mass surveillance and its impingement on civil liberties. Imam Zaid Shakir stated, "This is not a Muslim issue, but an American issue. We don't want other communities to go through what the Muslim community has gone through" (Craun, 2014:1). Successfully persuading the council to significantly scale back its plans to build a citywide surveillance center was a powerful organizing victory for U.S. Muslims that is resonating throughout the Bay Area and the nation.

Although these high profile examples represent relatively large-scale instances of U.S. Muslim civic engagement and collaboration, similar smaller-scale movements have taken place in 
communities around the country, including Atlanta, Minneapolis/St. Paul, Baltimore, Los Angeles, and Tacoma (Rurik, Izumizaki, \& Jasani, 2014). Through these efforts, Muslim civic engagement via faith-based organizing demonstrates U.S. Muslims' capacity to work collaboratively with nonMuslim communities and organizations to influence public policy. Particularly important for the success of these campaigns are three factors: (1) the ability to mobilize everyday Muslims who are not typically perceived to be political activists, and thus can garner greater credibility in policy circles (Collins, 2010); (2) the ability to remain engaged over sustained periods (measured in years) in order to help form and reform policy, build political credibility, and forge lasting coalitions with other organizations in favor of pragmatic policies that benefit not only Muslims but also other members of the community (Tesdahl, 2015); and (3) the ability of religious leaders to fluently connect pragmatic policy critiques and alternatives to the deep moral languages and ethical framing of their faith tradition (Wood \& Fulton, 2015).

During the same period in which these locally organized efforts have emerged, a number of foundations throughout the country have demonstrated an interest in faith-based community organizing as a tool for promoting Muslim civic engagement in the United States (Craun, 2014; Kobara, 2015; Mehdl, 2014; Morris, 2011; Rurik et al., 2014). One Nation Foundation, a philanthropic collaborative partnering with community foundations to strengthen U.S. Muslim communities, has funded several community-based initiatives, including faith-based organizing, as a strategy to reduce misperceptions of Muslims while fostering community resiliency (Rurik et al., 2014). From this collaborative effort emerged the One Nation Bay Area project, in which a consortium of funders came together to fund community-based organizations with an interest in deepening Muslim civic engagement projects in the San Francisco Bay Area (McAllister, 2012). Similarly, in Chicago the One Chicago One Nation initiative, which included the Chicago Community Trust, was launched with the aim of engaging Muslims within Chicago's diverse communities through interfaith social-action projects (J. Warren, 2010, 2011). Additionally, in New York City, the Mayor's Office of Immigrant Affairs and several NYC-based foundations, along with the One Nation Foundation, formed a strategic partnership to promote civic-based immigrant integration (Dolnick, 2011). These funders and foundations exhibit an expectation that faith-based organizing can provide a vehicle for Muslim communities to (1) strengthen themselves internally by developing civic leaders and mobilizing everyday U.S. Muslims to address issues affecting their community and (2) strengthen their external ties by bridging religious and social differences and by promoting policies that also benefit non-Muslims (Fulton \& Wood, 2012; Warren, 2009).

\section{Faith-Based Community Organizing}

Faith-based community organizing (FBCO) arises from the democratic ideals promoted by grassroots political activists such as Jane Addams, Saul Alinsky, Larry Itliong, Cesar Chavez, and Martin Luther King Jr., and shares roots with union organizing efforts and civil rights movements concerning the status of African Americans, Asian Americans, Latinos, and women (Bretherton, 2015; Orr, 2007; Smock, 2004; Wood, 2002). Ed Chambers of the Industrial Areas Foundation (IAF) pioneered early elements of organizing based explicitly in community institutions, which were often religious congregations, but also included a variety of secular institutions such as public schools, labor unions, and neighborhood associations (Stout, 2010; Swarts, 2008; Warren, 2001). Today, most FBCO organizations are affiliated with one of several sponsoring networks. 
Nationally, these include IAF, the PICO National Network, the Gamaliel Foundation, and National People's Action. Important regional networks include the Direct Action and Research Training Center (DART) in the Southeast and Midwest and the InterValley Project (IVP) in New England. In addition, a smaller number of FBCO organizations exist independent of the formal sponsoring networks. Although each of the organizations just mentioned has developed its own approach to organizing, all are built with community institutions as their foundations, and the similarities in their respective sets of organizing practices justify treating them collectively as one field of activity (Warren \& Wood, 2001).

Over the past decade and a half, the FBCO field has built a significant presence throughout the United States by building its member base among congregations and other community institutions (Wood, Fulton, \& Partridge, 2012). As of 2011, 189 local FBCO organizations existed in the United States, with a presence in 40 of the 50 states, and in every major city and most midmajor cities. Approximately $7 \%$ of all U.S. congregations are members of a local FBCO organization (Chaves, Anderson, \& Eagle, 2014). The people represented in these organizations (i.e., in the congregations and other types of member institutions) number over five million. Civic associations that incorporate such a large number of people are rare in U.S. history, and those that have accomplished this level of engagement (e.g., the American Anti-Slavery Society, the National American Woman Suffrage Association, and the American Red Cross) have profoundly shaped society (Skocpol, Ganz, \& Munson, 2000). ${ }^{1}$

FBCO organizations are typically nonprofit organizations, set up under section 501(c)3 or 501(c)4 of the IRS tax code, with the goal of empowering residents of poor, working-class, and middle-class communities to motivate the government and corporations to address community concerns (Schneider, 2006). Each organization recruits a broad array of community institutions to become dues-paying members. Members include not only religious congregations but also neighborhood associations, schools, immigrant organizations, and unions. Each organization is led by a board of directors comprising representatives from its member institutions. In addition, FBCO organizations employ organizers who work with their board members and member institutions to develop leaders, prioritize which issues to address, and implement action plans (Wood et al., 2012).

FBCO organizations also promote leadership among their member institutions, providing training to help participants organize their communities and promote public policies that will improve their communities' quality of life (Wood \& Fulton, 2015). The organizations sponsor "political actions" or "accountability sessions" at which they call on political officials to support particular public policies (Hart, 2001). Drawing on the faith traditions of their members, they undergird that call by articulating a vision of a thriving community (Fulton \& Wood, 2012). This model of organizing has a record of contributing to progressive policy changes in the areas of education, health care, immigration, affordable housing, policing, and living wages (Wood et al., 2012); the fields' most sophisticated practitioners have organized and trained long-standing teams of leaders in communities that previously suffered from a lack of effective democratic representation (Rusch, 2012).

The key historical threshold for such influential civic associations is mobilizing $1 \%$ of the U.S. population. The five million people represented by the FBCO field's member institutions easily exceed this figure $(\sim 1.5 \%)$. Note, however, that with this form of organizing, membership is composed of institutions rather than individuals, so the comparison is not exact. 
FBCO organizations bolster their public influence and achieve their objectives by exercising a mix of hard and soft power (Keohane \& Nye, 1998). Hard power derives from the internal relational work of coalition building; this power is projected into the public sphere when FBCO organizations, through the sheer weight of their numbers, hold political officials accountable. Soft power extends that relational power externally in more systematic ways via a wider set of organizing practices, including cultivating long-term relationships with political officials and other institutional leaders, negotiating policies, forming strategic alliances, and drawing on specialized policy expertise (Wood \& Fulton, 2015). Although the balance of hard and soft power varies by organization and the broader organizing networks with which they are affiliated, every FBCO organization uses its relational and cultural resources to prioritize social needs, propose possible solutions, and generate the urgency needed to ensure the swift implementation of those solutions (Hart, 2001).

With regard to strengthening the social fabric of U.S. society, the FBCO field demonstrates a growing capacity to produce outcomes that deviate from major social trends (Wood \& Fulton, 2015). Amid evidence that U.S. society is becoming increasingly fragmented (Fischer \& Mattson, 2009), FBCO organizations bring people together across racial, class, and religious lines. Indeed, FBCO organizations are among the most racially and socioeconomically diverse organizations in the United States (Braunstein, Fulton, \& Wood, 2014); FBCO organizations are, on average, more racially diverse than congregations and public schools. More than 50\% of all FBCO organizations' board members are people of color (Wood et al., 2012), whereas only 19\% of all nonprofit board members in the United States and only $13 \%$ of Fortune 500 board members are people of color (Lang, Donald, Orta, \& Hokoyama, 2011; Ostrower, 2007). In terms of socioeconomic diversity, more than $50 \%$ of FBCO organization board members have a household income of less than $\$ 50,000$ per year, and roughly $25 \%$ have less than a bachelor's degree (Wood et al., 2012). Although no nationally representative data on the socioeconomic status of nonprofit boards exist, general knowledge of the nonprofit sphere indicates that the FBCO field incorporates greater socioeconomic diversity than most nonprofit boards.

This unusual concentration of influence among individuals belonging to otherwise disadvantaged groups suggests that FBCO organizations provide a countervailing force against societal trends of increasing inequality (Neckerman \& Torche, 2007; Osterman, 2002). By developing leaders within marginalized communities, FBCO organizations are generating substantial political power among underrepresented populations to counterbalance the elites and lobbyists who currently dominate the political arena (Chambers \& Cowan, 2003; Ganz, 2009).

In general, FBCO organizations are dedicated to strengthening public life, building democratic power, and improving social conditions in poor, working-class, and middle-class communities (Fine, 2006; Smock, 2004). They bolster public life by identifying leaders (often from marginalized and/or historically disenfranchised groups) and developing them into effective advocates for their communities (Andrews, Ganz, Baggetta, Han, \& Lim, 2010). They contribute to democracy in the United States by grounding democratic action in the social institutions that structure the daily lives of individuals, families, and communities (Bretherton, 2015). In doing so, they help communities organize and generate power that can be channeled toward shaping public policy to meet needs at the local level, and increasingly at the state and national level as well (Wood \& Fulton, 2015). As a result, FBCO organizations have become significant partners in 
promoting civic engagement, encouraging political participation, and addressing social issues at all levels of government. ${ }^{2}$

As FBCO organizations engage in and impact the public sphere, they simultaneously strengthen their institutional members by developing a strong leadership base among their constituents (Flaherty \& Wood, 2004). In 2011 the FBCO field reported that more than 20,000 core leaders were playing active voluntary roles within local FBCO organizations and that more than 5,000 of those leaders had attended a multi-day training event in the past year (Wood et al., 2012). Through these multi-day intensive training programs and other ongoing leadership development workshops, and by providing members with opportunities to practice their leadership skills, FBCO organizations have allocated substantial resources to (1) equip leaders with critical analytical, interpersonal, managerial, and political skills (Wagner, 2008); (2) deepen religious leaders' understanding of organizing in their congregation and in the public sphere (Bretherton, 2015; Stout, 2010); and (3) cultivate lay leaders' democratic skills not only for local engagement but also for participation in higher-level political arenas (Wood \& Fulton, 2015). Furthermore, many FBCO organizations explicitly seek to develop minority members, who have been marginalized from the realm of legitimate democratic discourse, by empowering them to represent themselves within the decision-making structures of their organization and by affirming their particular culture, history, and challenges (Oyakawa, Fulton, \& Wood, 2015; Yukich, Fulton, \& Wood, 2016).

\section{Assessing Muslim Civic Engagement in the United States}

The FBCO model for promoting civic engagement and developing leaders-especially those who have been marginalized by mainstream society - resonates with many U.S. Muslims who aspire to develop civic skills and become leaders within their communities (Jamal, 2005; Sirin \& Katsiaficas, 2011). In particular, Muslim immigrants, who often have strong ties to a local mosque, may find faith-based organizing to be an approachable means of becoming civically engaged (Guo, Webb, Abzug, \& Peck, 2013; Levitt, 2008; Numrich \& Kniss, 2007). Furthermore, the leadership skills participants develop through community organizing can help accelerate their process of social integration and social mobility (Handy \& Greenspan, 2009; Smock, 2004). Little is known, however, about the scope and scale of U.S. Muslim participation in faith-based community organizing or in other forms of civic engagement.

A significant challenge with assessing Muslim civic engagement in the United States and its consequences is the limited data on Muslim civic participation at local and national levels (Read, 2015; Siddiqui, 2014). Data of this nature could help mosques, community organizations, and government entities better understand, represent, and address the needs of Muslim communities (Downey, 2009; Jamal, 2005). This information could also help potential funders who are seeking to promote Muslim civic participation, develop local leaders, and build community capacity (Rurik et al., 2014; Senzai \& Bazian, 2013; Siddiqui, 2010). With respect to the academic researchers, a greater amount and depth of data are needed to provide a deeper understanding and more comprehensive portrait of Muslim civic engagement.

2 See Osterman (2002), Gecan (2009), and Wood et al. (2012) for extensive, in-depth analyses that highlight the organizations' impact on specific social issues and the public arena in general. 
In 1999 Interfaith Funders conducted a national study that included every FBCO organization in the United States in order to provide a baseline for understanding this field of organizations (Warren \& Wood, 2001). ${ }^{3}$ This study offered a portrait of the FBCO field that informed practitioners and simultaneously credentialed the work of faith-based organizing for a broad circle of funders, researchers, advocates, and potential collaborators. Over the ensuing decade, however, both the global context and the FBCO field changed substantially, especially with regard to U.S. Muslims.

To highlight the expanding scope and scale of faith-based community organizing in the United States and to specifically examine its role in promoting Muslim civic engagement, this article uses data from the National Study of Community Organizing Organizations (NSCOO), which is a replication and expansion of the study conducted in 1999 (Fulton, Wood, \& Interfaith Funders, 2011). The population for the NSCOO included every FBCO organization in the United States that had an office address, at least one paid employee, and institutional members. Based on these criteria, the study identified 189 active organizations by using databases from every national and regional community organizing network, databases from 14 foundations that fund community organizing, and archived IRS 990 forms. The NSCOO surveyed the entire field of these organizations during the second half of 2011 by distributing an online survey to the director of each organization. Respondents were asked to provide extensive data on their organization's history, finances, and activities as well as detailed demographic information on their institutional members, board members, and employees. This census study achieved a response rate of $94 \%$, gathering data on 178 of the 189 organizations in the country and demographic information on the 4,145 member institutions, 2,939 board members, and 628 paid staff members affiliated with these organizations (Fulton, 2016).

The structure of the NSCOO enables the data to be analyzed at two levels - the field level, to demonstrate patterns in the field as a whole, and the organization level, to assess similarities and differences among individual FBCO organizations. The NSCOO also allows for customized analyses of FBCO involvement in addressing specific social issues as well as analyses of specific constituent's participation levels - as is the case with this article's focus on Muslim involvement. In addition, because the 2011 study replicated items from the 1999 study and included the organizations surveyed in 1999, analyses can assess changes in the field (and in individual organizations) over the past decade. This comparative model offers a more dynamic view than possible with only a one-time snapshot.

Since 1999 the FBCO field has grown substantially in its breadth, depth, and level of engagement. The number of FBCO organizations increased by $42 \%$, and the number of states with at least one organization increased from 33 to 40. At the same time, many organizations have expanded beyond core urban areas and now organize entire metropolitan and regional areas. In addition, many organizations have begun participating in multi-organizational collaborations and are addressing issues at higher levels of government. Although these organizations remain deeply embedded within their local communities, they now operate with a strategic vision that carries them into regional-, state-, and national-level work.

The FBCO field has been known by various names, including "congregation-based," "broadbased," and "institution-based" community organizing, all of which refer to similar organizing models that share common historical and institutional roots. 
The FBCO field has achieved this growth with fairly modest financial resources. Since 1999 the median annual revenue for FBCO organizations has increased from $\$ 150,000$ to $\$ 175,000$, but adjusted for inflation, this change actually represents a slight decline in revenue for the average organization. ${ }^{4}$ Funding sources have shifted significantly. Although FBCO organizations prioritize raising funds from their institutional members in order to protect the organization's autonomy, the percentage of funding that comes from member dues decreased from $22 \%$ to $15 \%$. The percentage of funding provided by the Catholic Campaign for Human Development decreased from $19 \%$ to $15 \%$, and the percentage provided by other faith-based funders decreased from $12 \%$ to $7 \%$. The overwhelming majority of faith-based funders are Christian, Jewish, and Unitarian-Universalist organizations, and the percentage of funding from Muslim organizations remains very limited. Meanwhile, the percentage of funding provided by secular foundations and corporations increased from 30\% to 39\%. In 2011 donations from corporations constituted $4.5 \%$ of total reported local organization revenues, with secular foundations constituting $34.5 \% .^{5}$

\section{Muslims Increasing Religious Diversity of FBCO Organizations}

The FBCO field exhibits substantial religious diversity among its member institutions, board members, and organizing staff. Although most of the member congregations are Mainline Protestant (32\%), Catholic (27\%), and Black Protestant (24\%), Evangelical, Jewish, and Muslim congregations are increasing their representation within the field. The growing presence of mosques as member institutions is particularly noteworthy because the FBCO field had almost no Muslim member institutions in 1999. Furthermore, although mosques make up approximately $0.6 \%$ of all religious congregations in the United States, they constitute approximately $1.3 \%$ of FBCO member congregations. ${ }^{6}$ In comparison, almost half of the congregations in the United States are Evangelical, yet they make up less than $5 \%$ of all $\mathrm{FBCO}$ member congregations. ${ }^{7}$ As FBCO organizations seek to involve a broad base of religious traditions, Evangelical congregations are poorly represented relative to their prevalence among U.S. congregations, whereas mosques are notably well represented. Furthermore, even though the overall percentage of Muslim member institutions is small, they are distributed throughout the FBCO organizations rather than concentrated within a small number of organizations. Twenty percent of FBCO organizations have at least one Muslim member institution, and 17\% have at least one Muslim and one Jewish member institution.

In 1999, $\$ 150,000$ had the purchasing power equivalent of approximately $\$ 202,000$ in 2011 (U.S. Bureau of Labor Statistics); the change would thus be a 12\% drop from 1999 to 2011. Part of the decrease in 2011 can be attributed to the effects of the Great Recession. Note though that the reported decrease pertains only to local FBCO organizations and does not reflect revenues of national-level organizing efforts, nor does it reflect pre-recession budget levels.

5 The 1999 data do not separate donations from corporations and donations from secular foundations.

6 Estimates based on data from the US Mosque Study (Bagby, 2011) and Hadaway and Marler (2005).

7 Estimates based on data from the National Congregations Study (Chaves et al., 2014). 
Similar patterns emerge when analyzing the religious affiliation of FBCO board members and organizing staff. Among the board members, Muslims make up 1.5\% of members and are distributed throughout $19 \%$ of the organizations. With regard to organizing staff, in 1999 the entire field had only one Muslim organizer; as of 2011 there were nine. Although both the absolute number and the percentage of Muslim institutions and people in the FBCO field are small, more than $25 \%$ of the organizations have at least one Muslim member institution, board member, or staff person, and Muslim representation in the field substantially exceeds Muslim representation in U.S. society (see Figure 1). Furthermore, there is tremendous social significance for the FBCO field to transition from having essentially no Muslim involvement to having some Muslim involvement in one out of four organizations, and for a local FBCO organization to transition from having no Muslim member institutions or board members to having at least one. ${ }^{8}$

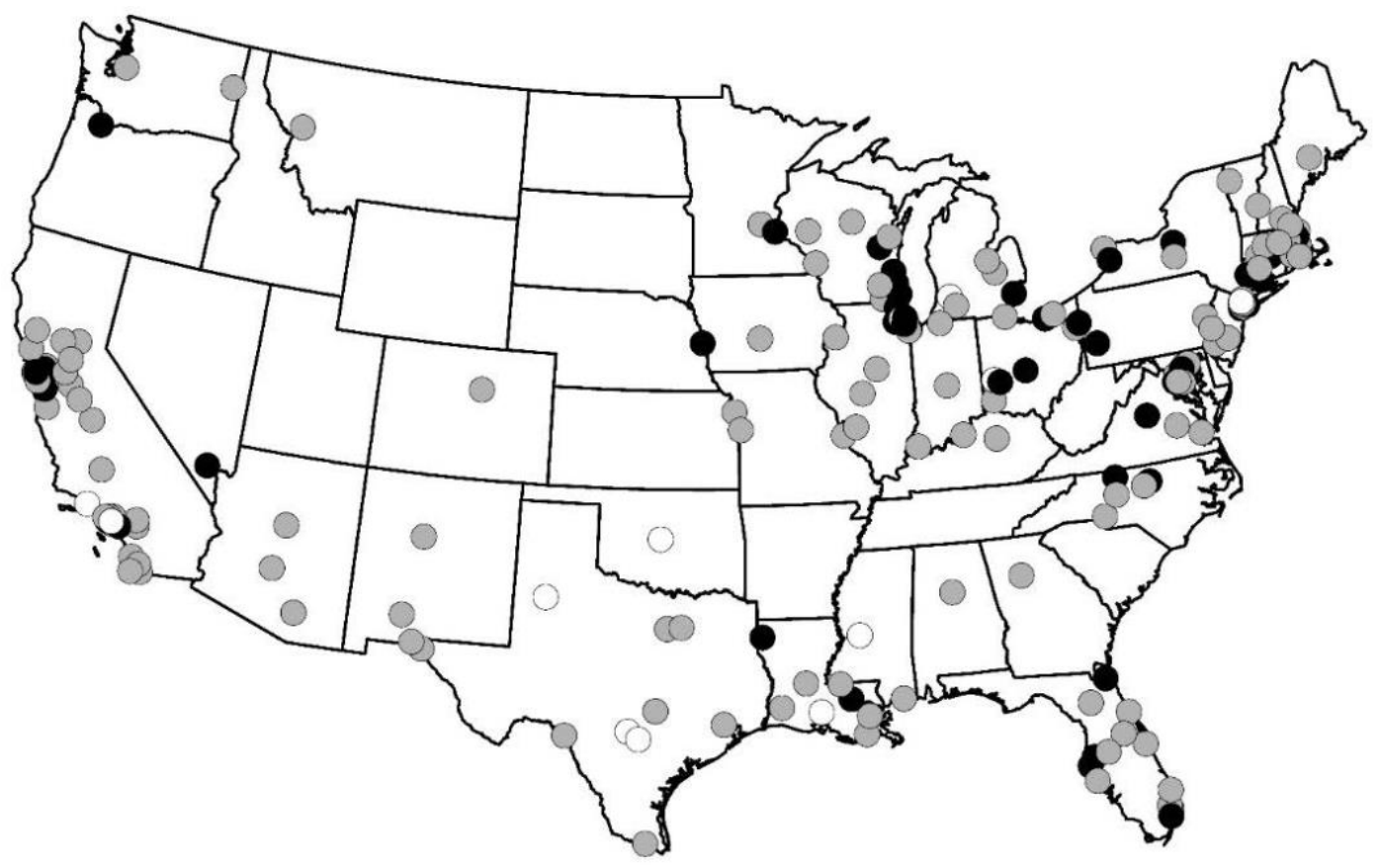

Figure 1. Muslim representation among faith-based community organizing organizations in the United States.

Key:

- Organization with Muslim representation

- Organization with no Muslim representation

O Organization with no data on religious affiliation

Source: 2011 National Study of Community Organizing Organizations $(\mathrm{N}=189)$ 


\section{Multi-Faith FBCO Organizations Navigating Religious Differences}

As FBCO organizations have become more religiously diverse and have included an increasing number of non-Christian faith traditions, they have had to develop strategies for navigating religious differences. Even though the leaders of FBCO organizations are often encouraged to draw on their specific faith traditions, they seldom focus on their religious differences. Most of the organizations reported discussing religious differences only "rarely" to "sometimes," and most indicated that religious differences had a minimal effect on their planning meetings. Likewise, those organizations that were more religiously diverse were no more likely than less diverse organizations to indicate that religious differences complicated, prolonged, or hindered their planning meetings. However, there are a few exceptions. Organizations that had at least one Muslim or Jewish member institution were more likely to report that religious differences complicated their planning meetings. One director specifically noted that Muslim prayer occasionally interrupted and prolonged the organization's planning meetings. Another director of a religiously diverse organization, which included Muslims, noted an ongoing tension to ensure that all of the faith traditions can participate, and she explained that her organization had not been completely successful at accomplishing this goal. In addition, organizations that frequently discuss religious differences were more likely to report that their differences affected their planning meetings, but it is important to clarify that an organization's propensity to discuss religious differences was unrelated to its degree of religious diversity. Furthermore, the directors of religiously diverse organizations did not report greater difficulty in accommodating different faith traditions in their organizing work than did directors of less diverse organizations.

As members of FBCO organizations from diverse faith traditions work together to improve their communities, they appear to navigate their religious differences by downplaying them. In an increasingly polarized political culture, in which religious differences are often used to amplify political disagreements, FBCO organizations are thus strikingly countercultural. Rather than using differences to pit faith communities against each other (or to antagonize divergent strands within a particular tradition), FBCO culture seeks to transcend their differences by focusing on shared values and pursuing common goals. This evidence suggests that religiously diverse organizations avoid potential conflicts and maintain cohesion by choosing to not focus on religious differences.

\section{Multi-Faith FBCO Organizations Harnessing Religion Despite Differences}

Despite the FBCO field's tendency to de-emphasize religious differences, religious teaching and practices continue to be an integral part of the organizations' internal and external activities. Sixty percent of the organization offices contain objects with religious references, and $80 \%$ of the organizations reported that their promotional material contains religious content. Furthermore, the directors are, on average, more religious than the general U.S. population (i.e., they pray, read sacred texts, and attend religious services more often than the average U.S. adult) (Smith, Marsden, Hout, \& Kim, 2011), and most FBCO organizations actively integrate religious practices into their organizing activities. More than $90 \%$ of the organizations reported that they often open and close their meetings with a prayer, and more than $75 \%$ often have discussions about the connection between faith and organizing. Many organizations also draw on religion as they build an organizational culture for political engagement. For example, most organizations' public activities include music, stories, and symbols rooted in their represented faith traditions. Given that FBCO 
organizations primarily comprise religious congregations, religion functions as a key mechanism by which these groups live out their commitment to improve the quality of life for disadvantaged communities.

Increasing the religious diversity of an FBCO organization does not seem to dampen the influence of religious faith in the organization. In fact, religiously diverse organizations are more likely to incorporate religious practices into their organizing activities, and the directors of diverse organizations reported feeling more comfortable doing so. Furthermore, socially diverse organizations often draw on religious practices to help bridge their members' racial and socioeconomic differences (Braunstein et al., 2014). Overall, rather than being venues for interfaith dialogue, FBCO organizations are vehicles for interfaith action. Instead of discussing potentially divisive differences, faith-based organizing forms relationships between leaders of differing faiths and harnesses their shared beliefs to motivate and mobilize them around issues of common concern. Moreover, an organization's tendency to incorporate religious elements is strongest among those that are religiously diverse and led by religiously active directors.

The FBCO field's success at achieving, navigating, and harnessing religious diversity occurs at a time when religious traditions are struggling to retain and redefine the place of religion in the public sphere (Fulton \& Wood, 2017a). Culturally defensive religious forms - and at times explicitly anti-intellectual and fundamentalist expressions of them-have come to dominate religiously framed public discourse, at least in the popular perception conveyed in media coverage (Beckford, 2000; Wood \& Fulton, 2015). This perception is pervasive and has been fueled by isolated cases of fanaticism and extremism, which undermines the credibility of religious voices in the public sphere (Dionne, 2009). It remains an open question how much faith-based community organizing will contribute to strengthening public religion and reestablishing a credible religious voice for deepening civic engagement (Fulton \& Wood, 2017b). FBCO's likelihood of helping religious communities achieve this civic credibility lies in its unique capacity to bridge religious differences and then harness those differences to promote the common good.

\section{Conclusion}

As U.S. Muslim communities, along with other members of U.S. society, seek to confront the escalating social and economic challenges of the 21 st century, it is critical to generate new sources of democratic vigor, provide pathways for civic engagement, and promote broad-based collaborations. Faith-based community organizing offers a compelling and comprehensive model for accomplishing these goals by developing civic leaders from diverse backgrounds to work together to address issues of common concern. In particular, faith-based organizing is well positioned to meet the needs of Muslim communities through encouraging political participation, promoting collaborations, increasing community capacity, and preserving religious vitality.

Faith-based community organizing actively promotes expanding grassroots political participation, which includes voter registration drives, voter education forums, and get-out-thevote campaigns (Wood \& Fulton, 2015). As Muslim leaders contribute to planning these initiatives, they can help design and promote such activities in ways that appeal to the values of U.S. Muslims, thereby increasing the likelihood of Muslim participation. Embracing and endorsing these political participation initiatives can help Muslim communities develop the skills and capacities they need to increase civic engagement. 
Efforts by U.S. Muslim leaders to organize their communities and collaborate with nonMuslims can be supported through involvement in local FBCO organizations, which have an organizational structure that encourages participation from a wide variety of community members and an organizational culture that facilitates collaborations across social differences. Participating in such community-based collaborations can produce a deepened sense of interfaith and multicultural cooperation and partnership for the collective good (Wood \& Fulton, 2015). Additionally, participating in FBCO organizations can help strengthen Muslim communities' institutional infrastructure through developing leaders and increasing organizational capacity. This leadership development may be particularly critical for nascent organizations or organizations composed primarily of Muslim immigrants or indigenous U.S. Muslims from disadvantaged socioeconomic backgrounds.

Finally, faith-based organizing offers a welcoming setting for religiously active Muslims to become civically engaged. In such settings, rather than feeling the need to suppress their deeply held religious beliefs and practices, they are encouraged to harness their faith to help advance the goals of the organization (Wood \& Fulton, 2015). Harnessing their faith to support civic efforts for the public good can also help non-Muslims develop a greater understanding and appreciation of the Islamic faith and see how many of its core values overlap with those of their own faith traditions.

Overall, for foundations seeking to encourage U.S. Muslims to participate in civic life, engage in participatory governance, and work together with non-Muslims, faith-based organizing can provide an accessible pathway to accomplish these goals. Although Muslim communities have been increasing their civic participation through faith-based organizing, many foundations inclined to support Muslim civic engagement have been slow to fund these organizing efforts. Having additional financial resources could help catalyze greater Muslim involvement and advance the goals of faith-based organizing. By funding FBCO organizations, foundations would be investing in organizations that promote Muslim civic engagement, develop Muslim leaders, and strengthen Muslim institutions, and at the same time, encourage partnerships with non-Muslim leaders and organizations. 


\section{References}

Andrews, K. T., Ganz, M., Baggetta, M., Han, H., \& Lim, C. (2010). Leadership, membership, and voice: Civic associations that work. American Journal of Sociology, 115, 1191-1242.

Bagby, I. (2011). The American Mosque 2011: Report Number 1 from the US Mosque Study 2011. Washington, DC: Council on American-Islamic Relations.

Beckford, J. A. (2000). Religious movements and globalization. In R. Cohen \& S. M. Rai (Eds.), Global social movements (pp. 165-183). New York, NY: Continuum.

Braunstein, R., Fulton, B. R., \& Wood, R. L. (2014). The role of bridging cultural practices in racially and socioeconomically diverse civic organizations. American Sociological Review, 79, 705-725.

Bretherton, L. (2015). Resurrecting democracy: Faith, citizenship, and the politics of the common good. New York, NY: Cambridge University Press.

Chambers, E. T., \& Cowan, M. A. (2003). Roots for radicals: Organizing for power, action, and justice. New York, NY: Continuum.

Chaves, M., \& Anderson, S. L. (2014). Changing American congregations: Findings from the third wave of the National Congregations Study. Journal for the Scientific Study of Religion, 53, 676-686.

Chaves, M., Anderson, S., \& Eagle, A. (2014). National congregations study: Cumulative datafile and codebook. Durham, NC: Duke University, Department of Sociology.

Collins, P. H. (2010). The new politics of community. American Sociological Review, 75, 7-30.

Craun, D. (2014, April 9). Building congregation-based organizing in the Muslim community.

The San Francisco Foundation. Retrieved from http://sff.org/building-congregation-basedorganizing-in-the-muslim-community/\#sthash.62pJMtiB.dpuf

Dionne Jr., E. J. (2009). Souled out: Reclaiming faith and politics after the religious right. Princeton, NJ: Princeton University Press.

Dolnick, S. (2011, April 11). Helping immigrants navigate government. The New York Times, p. A19.

Downey, D. J. (2009). Institutional activism and community building: Human relations responses to 9/11 in Orange County, California. American Behavioral Scientist, 53, 99-113.

Fine, J. (2006). Worker centers: Organizing communities at the edge of the dream. Ithaca, NY: Cornell University Press.

Fischer, C. S., \& Mattson, G. (2009). Is America fragmenting? Annual Review of Sociology, 35, 435-455.

Flaherty, M. A., \& Wood, R. L. (2004). Faith and public life: Faith-based community organizing and the development of congregations. New York, NY: Interfaith Funders.

Freedman, S. G. (2014, November 15). Building bridges where needed on Chicago's South Side. The New York Times, p. A16. 
Fulton, B. R. (2016). Organizations and survey research: Implementing response enhancing strategies and conducting nonresponse analyses. Sociological Methods \& Research. Advance online publication. doi:10.1177/0049124115626169

Fulton, B. R., \& Wood, R. L. (2012). Interfaith community organizing: Emerging theological and organizational challenges. International Journal of Public Theology, 6, 398-420.

Fulton, B. R., \& Wood, R. L. (2017a). Achieving and leveraging diversity through faith-based organizing. In R. Braunstein, T. N. Fuist, \& R. H. Williams (Eds.), Religion and progressive activism (pp. 29-55). New York, NY: New York University Press.

Fulton, B. R., \& Wood, R. L. (2017b). Civil society organizations and the enduring role of religion in democratic engagement. Voluntas.

Fulton, B. R., Wood, R. L., \& Interfaith Funders. (2011). National Study of Community Organizing Organizations. Retrieved from http://blogs.iu.edu/fulton/files/2012/12/Wood-Fultonand-Partridge_2012_Building-Bridges-Building-Power-1adr3ac.pdf

Ganz, M. (2009). Why David sometimes wins: Leadership, organization, and strategy in the California farm worker movement. New York, NY: Oxford University Press.

Gecan, M. (2009). After america's midlife crisis. Cambridge, MA: MIT Press.

Goodman, J. D. (2013, August 14). As critics united, stalled battle against frisking tactic took off. The New York Times, p. A1.

Guo, C., Webb, N. J., Abzug, R., \& Peck, L. R. A. (2013). Religious affiliation, religious attendance, and participation in social change organizations. Nonprofit and Voluntary Sector Quarterly, 42, 34-58.

Hadaway, C. K., \& Marler, P. L. (2005). How many Americans attend worship each week? An alternative approach to measurement. Journal for the Scientific Study of Religion, 44, 307-322.

Handy, F., \& Greenspan, I. (2009). Immigrant volunteering: A stepping stone to integration? Nonprofit and Voluntary Sector Quarterly, 38, 956-982.

Hart, S. (2001). Cultural dilemmas of progressive politics: Styles of engagement among grassroots activists. Chicago, IL: University of Chicago Press.

Jamal, A. (2005). The political participation and engagement of Muslim Americans mosque involvement and group consciousness. American Politics Research, 33, 521-544.

Kane, A. (2013, January 30). From Islamophobic surveillance to 'stop and frisk': Organizers decry criminalization of their communities in NYC. Mondoweiss. Retrieved from http://mondoweiss.net/2013/01/islamophobic-surveillancecriminalization\#sthash.dgrGfonn.dpuf

Keohane, R. O., \& Nye, J. S. (1998). Power and interdependence in the information age. Foreign Affairs, 77, 81-94.

Kobara, J. E. (2015, March 31). American Muslims and philanthropy. Huffington Post. doi:http://www.huffingtonpost.com/john-e-kobara/american-muslims-andphil_1_b_6935756.html 
Lang, I., Donald, A. W., Orta, C. F., \& Hokoyama, J. D. (2011). Missing pieces: Women and minorities on Fortune 500 boards. 2010 Alliance for Board Diversity Census. New York, NY: Catalyst.

Levitt, P. (2008). Religion as a path to civic engagement. Ethnic and Racial Studies, 31, 766791.

Lyden, J. (2013, February 16). From the inner city: Leading a new generation of Muslim Americans. National Public Radio. Retrieved from http://www.npr.org/2013/02/16/172191234/from-the-inner-city-leading-a-new-generation-ofmuslim-americans

McAllister, S. (2012, March 1). Bay Area funders and community leaders address anti-Muslim bias. Silicon Valley Community Foundation. Retrieved from http://www.siliconvalleycf.org/press-release-march-1-2012

Mehdl, A. (2014, March 31). American Muslims: Into the public square. El-Hibri Foundation. doi:http://www.elhibrifoundation.org/news/american-muslims-into-the-public-square

Morris, N. (2011, January 1). Working to boost social activism among Muslims. Los Angeles Times. doi:http://articles.latimes.com/2011/jan/01/local/la-me-beliefs-community-20110101

Neckerman, K., \& Torche, F. (2007). Inequality: Causes and consequences. Annual Review of Sociology, 33, 335-357.

Numrich, P., \& Kniss, F. (2007). Sacred assemblies and civic engagement: How religion matters for America's newest immigrants. New Brunswick, NJ: Rutgers University Press.

Orr, M. (2007). Transforming the city: Community organizing and the challenge of political change. Lawrence, KS: University Press of Kansas.

Osterman, P. (2002). Gathering power: The future of progressive politics in America. Boston, MA: Beacon Press.

Ostrower, F. (2007). Nonprofit governance in the United States: Findings on performance and accountability from the first national representative study. Washington, DC: The Urban Institute.

Oyakawa, M., Fulton, B. R., \& Wood, R. L. (2015). Critical standpoint: Leaders of color advancing racial equality in predominantly white organizations. Paper presented at the American Sociological Association Annual Meeting, Chicago, IL.

Parsons, M. (2013, February 5). Chicago is ground zero in U.S. Muslim renaissance. The Washington Post. Retrieved from https://www.washingtonpost.com/national/on-faith/chicago-isground-zero-in-us-muslim-renaissance/2013/02/05/f6516b74-6fd9-11e2-b3f3-

b263d708ca37_story.html

Read, J. G. (2015). Gender, religious identity, and civic engagement among Arab Muslims in the United States. Sociology of Religion, 76, 30-48.

Rurik, C., Izumizaki, H., \& Jasani, N. (2014). Never second-guess the locals. In T. Mazany \& D. C. Perry (Eds.), Here for good: Community foundations and the challenges of the 21st century (pp. 144-154). New York, NY: M. E. Sharpe. 
Rusch, L. (2012). Going regional: The evolution of an organizing strategy in Detroit. City \& Community, 11, 51-73.

Schneider, J. A. (2006). Social capital and welfare reform: Organizations, congregations, and communities. New York, NY: Columbia University Press.

Senzai, F., \& Bazian, H. (2013). The Bay Area Muslim study: Establishing identity and community. Washington, DC: Institute for Social Policy and Understanding.

Siddiqui, S. A. (2010). Giving in the way of God: Muslim philanthropy in the United States. In D. H. Smith (Ed.), Religious giving: For love of God (pp. 28-48). Bloomington, IN: Indiana University Press.

Siddiqui, S. A. (2014). Navigating identity through philanthropy: A history of the Islamic society of North America (1979-2008) (Doctoral dissertation). Indiana University, Indianapolis.

Sirin, S. R., \& Katsiaficas, D. (2011). Religiosity, discrimination, and community engagement: Gendered pathways of Muslim American emerging adults. Youth \& Society, 43, 1528-1546.

Skocpol, T., Ganz, M., \& Munson, Z. (2000). A nation of organizers: The institutional origins of civic voluntarism in the United States. American Political Science Review, 94(3). 527-546.

Smith, T. W., Marsden, P. V., Hout, M., \& Kim, J. (2011). General Social Survey, 1972-2010:

Cumulative codebook. Chicago, IL: National Opinion Research Center.

Smock, K. (2004). Democracy in action: Community organizing and urban change. New York, NY: Columbia University Press.

Stout, J. (2010). Blessed are the organized: Grassroots democracy in America. Princeton, NJ: Princeton University Press.

Swarts, H. J. (2008). Organizing urban America: Secular and faith-based progressive movements. Minneapolis, MN: University of Minnesota Press.

Tesdahl, E. A. (2015). More than the sum of its parts: Cooperation and mutual commitment in multi-issue congregation-based community organizing. Sociological Inquiry, 85, 148-171.

Wagner, A. (2008). Religion and civil society: A critical reappraisal of America's civic engagement debate. Nonprofit and Voluntary Sector Quarterly, 37, 626-645.

Warren, J. (2010, January 15). A street-level campaign intends to take on bigotry. The New York Times, p. A19A.

Warren, J. (2011, August 5). One Nation, One Chicago strives for interfaith understanding. The New York Times, p. A19A.

Warren, M. R. (2001). Dry bones rattling: Community building to revitalize American democracy. Princeton, NJ: Princeton University Press.

Warren, M. R. (2009). Community organizing in Britain: The political engagement of faithbased social capital. City \& Community, 8, 99-127.

Warren, M. R., \& Wood, R. L. (2001). Faith-based community organizing: The state of the field. Jericho, NY: Interfaith Funders. 
Winston, A. (2014, March 5). Oakland City Council rolls back the Domain Awareness Center. East Bay Express. Retrieved from http://www.eastbayexpress.com/SevenDays/archives/ 2014/03/05/oakland-city-council-rolls-back-the-dac

Wood, R. L. (2002). Faith in action: Religion, race, and democratic organizing in America. Chicago, IL: University of Chicago Press.

Wood, R. L., \& Fulton, B. R. (2015). A shared future: Faith-based community organizing for racial equity and ethical democracy. Chicago, IL: University of Chicago Press.

Wood, R. L., Fulton, B. R., \& Partridge, K. (2012). Building bridges, building power:

Developments in institution-based community organizing. Denver, CO: Interfaith Funders.

Yukich, G., Fulton, B. R., \& Wood, R. L. (2016). Representative group styles: How ally immigrant rights organizations promote immigrant involvement. Paper presented at the Academy of Management Annual Meeting, Anaheim, CA. 